\title{
Disability Adjusted Life Years (DALYs) in Terms of Years of Life Lost (YLL) Due to Premature Adult Mortalities and Postneonatal Infant Mortalities Attributed to $\mathbf{P M}_{2.5}$ and $\mathbf{P M}_{10}$ Exposures in Kuwait
}

\author{
Ali Al-Hemoud ${ }^{1, *}$, Janvier Gasana ${ }^{2}{ }^{\circledR}$, Abdullah N. Al-Dabbous ${ }^{1}$, Ahmad Al-Shatti ${ }^{3}$ and \\ Ahmad Al-Khayat ${ }^{4}$ \\ 1 Crisis Decision Support Program, Environment and Life Sciences Research Center, Kuwait Institute for \\ Scientific Research, P.O. Box 24885, 13109 Safat, Kuwait; adabbous@kisr.edu.kw \\ 2 Faculty of Public Health, Health Sciences Center, Kuwait University, P.O. Box 24923, 13110 Hawalli, Kuwait; \\ janvier.gasana@HSC.EDU.KW \\ 3 Occupational Health Department, Kuwait Ministry of Health, P.O. Box 51360, 53454 Riqqa, Kuwait; \\ ahmad.alshatti2011@yahoo.com \\ 4 Techno-Economics Division, Kuwait Institute for Scientific Research, P.O. Box 24885, 13109 Safat, Kuwait; \\ akhayat@kisr.edu.kw \\ * Correspondence: ahomood@kisr.edu.kw; Tel.: +09-652-498-9464
}

Received: 9 October 2018; Accepted: 17 November 2018; Published: 21 November 2018

\begin{abstract}
Ambient air pollution in terms of fine and coarse particulate matter $\left(\mathrm{PM}_{2.5}\right.$ and $\left.\mathrm{PM}_{10}\right)$ has been shown to increase adult and infant mortalities. Most studies have estimated the risk of mortalities through attributable proportions and number of excess cases with no reference to the time lost due to premature mortalities. Disability adjusted life years (DALYs) are necessary to measure the health impact of Ambient particulate matter (PM) over time. In this study, we used life-tables for three years (2014-2016) to estimate the years of life lost (YLL), a main component of DALYs, for adult mortalities (age 30+ years) and postneonatal infant mortalities (age 28+ days-1 year) associated with $\mathrm{PM}_{2.5}$ exposure and $\mathrm{PM}_{10}$ exposure, respectively. The annual average of $\mathrm{PM}_{2.5}$ and $\mathrm{PM}_{10}$ concentrations were recorded as $87.9 \mu \mathrm{g} / \mathrm{m}^{3}$ and $167.5 \mu \mathrm{g} / \mathrm{m}^{3}$, which are 8 times greater than the World Health Organization (WHO) air quality guidelines of $10 \mu \mathrm{g} / \mathrm{m}^{3}$ and $20 \mu \mathrm{g} / \mathrm{m}^{3}$, respectively. Results indicated a total of 252.18 (95\% CI: 170.69-322.92) YLL for all ages with an increase of 27,474.61 (95\% CI: 18,483.02-35,370.58) YLL over 10 years. The expected life remaining (ELR) calculations showed that 30- and 65-year-old persons would gain 2.34 years and 1.93 years, respectively if the current $\mathrm{PM}_{2.5}$ exposure levels were reduced to the WHO interim targets (IT- $1=35 \mu \mathrm{g} / \mathrm{m}^{3}$ ). Newborns and 1-year old children may live 79.81 and 78.94 years, respectively with an increase in average life expectancy of 2.65 years if the WHO PM 10 interim targets were met $\left(\mathrm{IT}-1=70 \mu \mathrm{g} / \mathrm{m}^{3}\right)$. Sensitivity analyses for YLL were carried out for the years 2015, 2025, and 2045 and showed that the years of life would increase significantly for age groups between 30 and 85. Life expectancy, especially for the elderly ( $\geq 60$ years), would increase at higher rates if $\mathrm{PM}_{2.5}$ levels were reduced further. This study can be helpful for the assessment of poor air quality represented by $\mathrm{PM}_{2.5}$ and $\mathrm{PM}_{10}$ exposures in causing premature adult mortalities and postneonatal infant mortalities in developing countries with high ambient air pollution. Information in this article adds insights to the sustainable development goals (SDG 3.9.1 and 11.6.2) related to the reduction of mortality rates attributed to ambient air levels of coarse and fine particulate matter.
\end{abstract}

Keywords: AirQ+; burden of disease (BOD); DALYs; $\mathrm{PM}_{2.5}$; postneonatal mortality; YLD; YLL 


\section{Introduction}

Ambient particulate matter (PM) pollution has been associated with increased risk of premature adult mortalities [1-5] and postneonatal infant mortalities [6-10]. The largest cohort study, the American Cancer Society (ACS) study [11], reported a robust association between long-term exposure to fine inhalable particles $\left(\mathrm{PM}_{2.5}\right)$ and adult mortality (age $\geq 30$ years). The Harvard Six-Cities study also found a strong association between long-term exposure to $\mathrm{PM}_{2.5}$ and adult mortality, even after controlling for potential confounders, such as age, sex, or cigarette smoking [12]. Both the ACS and the Harvard studies were large prospective cohort investigations with approximately 500,000 and 8111 adults, respectively, followed up for a total duration of 26 years and 15 years, respectively, in order to explore the mortality rates associated with $\mathrm{PM}_{2.5}$ exposure after controlling for age, gender, education level, diet, body-mass index, cigarette smoking and occupational exposure. Both studies concluded that $\mathrm{PM}_{2.5}$ was positively related to daily mortality, particularly the elderly. Other recent studies have shown similar findings [2,13-18]. $\mathrm{PM}_{2.5}$ was ranked as the ninth leading risk factor with 3.1 million deaths and $3.1 \%$ of global disability adjusted life years (DALYs) in the 2010 global burden of disease (GBD) study $[19,20]$. In 2015 GBD, PM $_{2.5}$ was the fifth-ranking mortality with 4.2 million deaths and 103.1 million DALYs, representing $7.6 \%$ of total global deaths and $4.2 \%$ of global DALYs [21]. $\mathrm{PM}_{10}$ was also shown to increase the risk of mortality, but mostly to children and infants because of their higher susceptibilities to coarse particles $[8,22,23]$. Postneonatal mortality (after 28 days of life) is thought to be influenced by the infant's external environment [24,25].

Within the health risk assessment literature, neither can the probability of exceeding the air standard provide a conclusive evidence on the occurrence of detrimental health effects [26], nor can the incidence of health risk account for the severity and duration of the health impact [27]; therefore, the use of other internationally mortality metrics that address the human burden of disease (BOD) over the years are necessary $[28,29]$. One of the recently used common metrics is DALYs, which is particularly encompassing since, in addition to the number of deaths, it combines the estimation of time lived with disability and time lost due to premature mortality [30-33]. There are many applications for the use of DALYs in the assessment of the BOD; including airborne sources [20,26,34], foodborne sources [35-37], and waterborne sources [36,38,39]. DALYs values have been continuously updated [40], and improvement of DALYs measures can have a positive impact on the quality of life [41]. Calculation and reporting of disease burdens using DALYs tools have become a routine task of the World Health Organization (WHO) and will continue until $2020[27,42]$.

In 2016, the WHO developed the AirQ+ model, updated from the 2014 AirQ2.2 version, to calculate the health burden associated with exposure to the most relevant air pollutants, including $\mathrm{PM}_{2.5}, \mathrm{PM}_{10}$, ozone, nitrogen dioxide, and black carbon. Many studies across the world have used the AirQ+/AirQ2.2 model to quantify the BOD, including Italy [43,44], Poland [45], Greece [46], Estonia [47], Egypt [48], Iran [49-55], Saudi Arabia [56], and South Korea [57]. Although most of these studies quantified the health burden based on risk estimates, only three studies have used the life-tables approach to estimate the components of DALYs [43,47,49].

In the current study, the life-table approach using the AirQ+ model was used to estimate both premature adult mortalities associated with $\mathrm{PM}_{2.5}$ exposure and postneonatal infant mortalities associated with $\mathrm{PM}_{10}$ exposure for three years (2014-2016). Mortalities are estimated using the Years of Life Lost (YLL), a main component in the DALYs equation.

\section{Methods}

\subsection{Air Quality Data}

The urban districts in Kuwait are grouped into six governates for city planning and municipality services. Altogether, there are a total of 92 urban districts located within the six governates. There are a total of 16 fixed ambient air quality monitoring stations across Kuwait. All sixteen stations record $\mathrm{PM}_{10}$ concentrations, while only three stations record $\mathrm{PM}_{2.5}$ concentrations (Figure 1). 


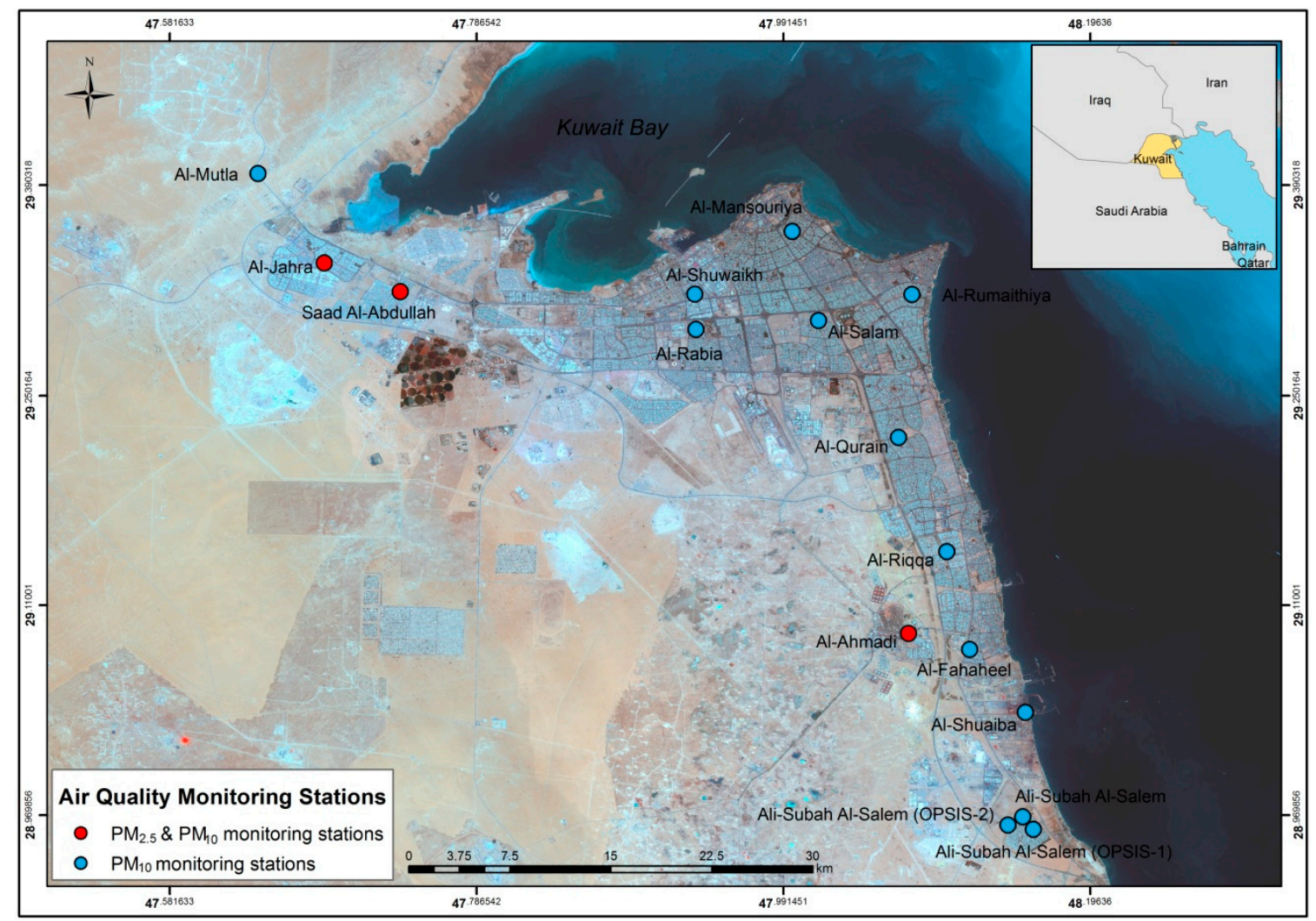

Figure 1. Map showing the location of the three $\mathrm{PM}_{2.5}$ monitoring stations in Kuwait (marked in red dots).

The study examined the daily data of real-time hourly concentrations of $\mathrm{PM}_{2.5}$ and $\mathrm{PM}_{10}$ for three years (2014-2016) in association with the collected baseline health data and life tables from the National Center for Health Information (NCHI) of Kuwait Ministry of Health. Careful filtration and processing of monitoring stations' data was carried out as per the Aphekom project [58]. Stations were excluded if any of the following three conditions existed: (1) more than $75 \%$ of missing data in any station; (2) the interquartile range of any station did not overlap with the other stations; (3) the correlation coefficients between stations were lower than 0.6. A fourth condition was added for reconfirmation, that the general acceptable ratio of $\mathrm{PM}_{2.5} / \mathrm{PM}_{10}$ should be within $0.5-0.65[59,60]$ or $0.35-0.5$ for desert arid regions $[59,61]$.

\subsection{Life Tables and DALYS}

Life tables including mid-year population and deaths by age groups were collected for three years (2014-2016) from the NCHI of Kuwait Ministry of Health. The Health and Vital Statistics Division of the NCHI reports annual health indicators in nine parts, including: demographics, socioeconomics, risk factors, health expenditure, health system, health coverage, health status, selected morbidity, and environmental indicators. Total population data were included in the first part (demographic indicator). Mortality and morbidity rates were included in the seventh part (health status indicator). A total of 18 age ranges were divided in into 5-year intervals from age $\leq 4$ years to age $\geq 85$ years. The YLL were estimated as a consequence of the impact of $\mathrm{PM}_{2.5}$ exposure on population mortality. The YLL is one of the two components in the DALYs equation, in addition to the years lived with disability (YLD). The YLL is a measure of the years lost through premature mortality, while the YLD is a measure of the lost years of healthy life through living in states of less than full health. The DALYs includes both measures and represents an indicator of life expectancy, combining both mortality and morbidity into one summary measure of population health that accounts for the number of years lived 
in less than optimum health [33]. The basic formulas for calculating DALYs, YLL, and YLD in terms of specific diseases are expressed as [62]:

$$
\begin{aligned}
\text { DALYS } & =\mathrm{YLL}+\mathrm{YLD} \\
\mathrm{YLL} & =\mathrm{N} \times \mathrm{L} \\
\mathrm{YLD} & =\mathrm{I} \times \mathrm{D} \times \mathrm{L}
\end{aligned}
$$

where N: number of premature deaths; L: standard life expectancy at age of death (years) in Equation (2) or average duration of disability (years) in Equation (3); I: incident cases (i.e., disabilities); and D: disability weight.

The life table evaluation was conducted using the all (natural) cause mortality for adults (age 30+ years) and postneonatal mortalities (age 28+ days-1 year) as the health endpoints. The total Kuwaiti population for 2014, 2015, and 2016 were estimated as 1,258,254, 1,291,401, and 1,321,593, respectively, as per the consensus data from the Kuwait national statistical office.

\subsection{AirQ+ Model}

This study used recently available AirQ+ software (WHO Regional Office for Europe, Bonn, Germany) (2016), which was designed to quantify the health impact of exposure to air pollution. The tool was developed by the World Health Organization (WHO) regional office for Europe (Bonn office, Germany) to estimate the potential health effects of varied pollutants, including $\mathrm{PM}_{2.5}, \mathrm{PM}_{10}, \mathrm{NO}_{2}, \mathrm{O}_{3}$, and black carbon. The AirQ+/AirQ2.2 model was suggested as a reliable tool to estimate the detrimental health effects associated with air pollutants [63] and has been applied internationally to quantify the BOD (Table 1). The AirQ+ model estimates the attributable proportion (AP) of mortalities, the attributable excess incidence per 100,000 (EI), the attributable excess cases, and the YLL after inserting the calculation parameters and the life tables. The calculation parameters inserted into the model include the concentration cut-off value, PM mean concentration, health endpoint baseline incidence and the relative risk (RR). Because of to the high PM concentration levels in Kuwait, the AirQ+ technical officer of the WHO (personal communication) recommended the use of the linear-log RR Equation (4):

$$
\begin{gathered}
\mathrm{RR}_{\operatorname{lin}-\log }(\mathrm{C})=\exp \beta\left[\ln (\mathrm{C}+1)-\ln \left(\mathrm{C}_{0}+1\right)\right] \\
\mathrm{AP}=(\mathrm{RR}-1) / \mathrm{RR} \\
\mathrm{EI}=\mathrm{AP} \times \mathrm{BI} \\
\mathrm{EC}=\mathrm{EI} \times \mathrm{N}
\end{gathered}
$$

where $\beta$ is the empirical parameter that denotes the change in the relative risk for one-unit change in the concentration $C$ [64]. $C$ denotes the annual mean pollutant concentration, and $C_{0}$ denotes the cut-off or counterfactual concentration below which one chooses not to quantify the health impact because minimal significant effect on survival has been observed. The cut-off values were selected based on the WHO interim target levels IT- 1 as $35 \mu \mathrm{g} / \mathrm{m}^{3}$ and $70 \mu \mathrm{g} / \mathrm{m}^{3}$ for $\mathrm{PM}_{2.5}$ and $\mathrm{PM}_{10}$, respectively. $\mathrm{AP}$ is the attributable proportion (impact fraction): the fraction (percentage) of the health outcome (i.e., postneonatal infant mortality) attributed to the $\mathrm{PM}_{10}$ exposure; $\mathrm{EI}$ is the excess incidence: the estimated number of attributable cases per 100,000 population at risk; $\mathrm{BI}$ is the baseline incidence: the population incidence of the given health effect per 100,000; EC is the excess cases (i.e., the expected number of excess deaths attributed to $\mathrm{PM}_{10}$ exposure); $\mathrm{N}$ is the relevant exposed population for the health effect. Health endpoint parameters used in this work are summarized in Table 2. 
Table 1. International use of the AirQ+/AirQ2.2 model.

\begin{tabular}{|c|c|c|c|c|c|c|c|}
\hline Country * & $\mathbf{P M}_{2.5}$ & $\mathbf{P M}_{10}$ & $\mathbf{A P}$ & YLL & \multicolumn{3}{|c|}{ Reference } \\
\hline Egypt & $\sqrt{ }$ & & $\sqrt{ }$ & & \multicolumn{3}{|c|}{ Wheida et al., 2018} \\
\hline Estonia & $\sqrt{ }$ & $\sqrt{ }$ & $\sqrt{ }$ & $\sqrt{ }$ & \multicolumn{3}{|c|}{ Orru et al., 2009 ** } \\
\hline $\begin{array}{l}23 \text { European } \\
\text { Cities }\end{array}$ & $\sqrt{ }$ & $\sqrt{ }$ & $\sqrt{ }$ & & \multicolumn{3}{|c|}{ Boldo et al., 2006} \\
\hline Greece & & $\sqrt{ }$ & $\sqrt{ }$ & & \multicolumn{3}{|c|}{ Moustris et al., 2017} \\
\hline Iran & $\sqrt{ }$ & $\sqrt{ }$ & $\sqrt{ }$ & $\sqrt{ }$ & \multicolumn{3}{|c|}{$\begin{array}{l}\text { Faridi et al., 2018 }{ }^{* *} \text {; Ghozikali et al., 2016; } \\
\text { Goudarzi et al., 2017; Hadei et al., 2018; Hopke et al., } \\
\text { 2018; Khaniabadi et al., 2018; Miri et al., } 2017\end{array}$} \\
\hline Italy & $\sqrt{ }$ & $\sqrt{ }$ & $\sqrt{ }$ & $\sqrt{ }$ & \multicolumn{3}{|c|}{ Fattore et al., $2011^{* *}$; Tominz et al., 2005} \\
\hline Poland & & $\sqrt{ }$ & $\sqrt{ }$ & & \multicolumn{3}{|c|}{ Skotak and Swiatczak, 2008} \\
\hline Saudi Arabia & & $\sqrt{ }$ & $\sqrt{ }$ & & \multicolumn{3}{|c|}{ Habeebullah, 2013} \\
\hline South Korea & & $\sqrt{ }$ & $\sqrt{ }$ & & \multicolumn{3}{|c|}{ Jeong, 2013} \\
\hline \multicolumn{8}{|c|}{$\begin{array}{l}\text { *In alphabetical order; }{ }^{* *} \text { Study estimated both the AP and YLL. AP: Attributable Proportion: The fraction of the } \\
\text { health outcome (i.e., postneonatal infant mortality) attributed to the } \text { PM }_{10} \text { exposure. YLL: Years of Life Lost. }\end{array}$} \\
\hline $\begin{array}{l}\text { Health } \\
\text { Endpoint }\end{array}$ & \multicolumn{2}{|c|}{ Exposure } & \multicolumn{2}{|c|}{$\begin{array}{l}\text { Cut-off Value } \\
\quad\left(\mu \mathrm{g} / \mathrm{m}^{3}\right)\end{array}$} & $\begin{array}{l}\text { Annual Mean } \\
\left(\mu \mathrm{g} / \mathrm{m}^{3}\right)\end{array}$ & $\mathbf{R} \mathbf{R}$ * & $\beta$ Coefficient * \\
\hline $\begin{array}{l}\text { Premature } \\
\text { adult mortality, } \\
\text { all causes }\end{array}$ & \multicolumn{2}{|c|}{$\mathrm{PM}_{2.5}$} & \multicolumn{2}{|c|}{35} & \multicolumn{2}{|r|}{$\begin{array}{c}1.062 \\
(1.04,1.083)\end{array}$} & $\begin{array}{c}0.2454 \\
(0.1600,0.3252)\end{array}$ \\
\hline $\begin{array}{l}\text { Postneonatal } \\
\text { infant mortality, } \\
\text { all causes }\end{array}$ & \multicolumn{2}{|c|}{$\mathrm{PM}_{10}$} & \multicolumn{2}{|c|}{70} & 167.5 & $\begin{array}{c}1.04 \\
(1.02,1.07)\end{array}$ & $\begin{array}{c}0.2976 \\
(0.1502,0.5134)\end{array}$ \\
\hline
\end{tabular}

* Values in parentheses are lower and upper bounds (95\% CI); RR: Relative Risk.

\section{Results}

\subsection{Baseline Health Data and PM Data}

The collected baseline health data and life tables from the NCHI of Kuwait Ministry of Health were examined in relation to the average daily data of $\mathrm{PM}_{2.5}$ and $\mathrm{PM}_{10}$ for three years (2014-2016). Application of the Aphekom data scrutiny method [58] revealed that 2015 was the only reliable year with an adequate record of air quality data of $\mathrm{PM}_{2.5}$ (Al-Ahmadi station) and $\mathrm{PM}_{10}$ (Al-Shuwaikh station, Al-Mansouriya station, Al-Salam station, Al-Fahaheel station). A goodness-of-fit test was carried out to determine whether the baseline health data were significantly different between the three years (2014-2016). Table 3 shows the adult and postneonatal mortalities for the three years. The chi-squared test showed no significant differences in mortality cases between the three years $\left(\chi^{2}=0.913, p>0.05\right.$, Sig $\left.=0.633\right)$. Accordingly, the baseline health data and life tables were analyzed for the year 2015 only. As shown in Table 2, the annual average $\mathrm{PM}_{2.5}$ and $\mathrm{PM}_{10}$ concentrations for 2015 were $87.9 \mu \mathrm{g} / \mathrm{m}^{3}$ and $167.5 \mu \mathrm{g} / \mathrm{m}^{3}$, respectively which are 8 times greater than the WHO Air Quality Guidelines $\left(\mathrm{PM}_{2.5}=10 \mu \mathrm{g} / \mathrm{m}^{3}\right.$ and $\left.\mathrm{PM}_{10}=20 \mu \mathrm{g} / \mathrm{m}^{3}\right)$ [5]. 
Table 3. Adult and postneonatal mortalities for three years (2014-2016).

\begin{tabular}{cccc}
\hline Mortality & $\mathbf{2 0 1 4}$ & $\mathbf{2 0 1 5}$ & $\mathbf{2 0 1 6}$ \\
\hline Adult & 2561 & 2735 & 2685 \\
Postneonatal & 73 & 76 & 86 \\
\hline \multicolumn{4}{c}{ Pearson Chi-Square $\left(\chi^{2}\right)=0.913, \mathrm{df}=2$, Sig $=0.633}$.
\end{tabular}

\subsection{Premature Adult Mortality}

Table 4 presents the YLL due to premature mortality attributed to the long-term exposure of $\mathrm{PM}_{2.5}$ of $87.9 \mu \mathrm{g} / \mathrm{m}^{3}$. Results indicate that during 2015 there was a total of 252.18 (95\% CI: 170.69-322.92) YLL for all ages and 89.53 (95\% CI: 60.60-114.64) YLL for ages 0-64. Over ten years (2025), the results showed an increase of 27,474.61 (95\% CI: 18,483.02-35,370.58) YLL for all ages and 8487.28 (95\% CI: 5741.46-10,873.33) YLL for ages 0-64. Table 5 shows the expected life remaining (ELR) for different age groups: ages 0 and 1 for postneonatal, and ages 30 to 85 for adults. The delta ELR presents the difference between the ELR at the cut-off level $\left(35 \mu \mathrm{g} / \mathrm{m}^{3}\right)$ and the ELR at the measured level $\left(87.9 \mu \mathrm{g} / \mathrm{m}^{3}\right.$ ) (WHO 2016b). A 30-year-old is expected to live 51.12 more years at the current $\mathrm{PM}_{2.5}$ exposure. If the exposure were reduced to the cut-off level, the 30-year-old would gain 2.34 years (95\% CI: 1.53-3.08). Similarly, the life expectancy of a 65-year-old may increase by 1.93 years (95\% CI: 1.26-2.56) above his/her ELR of 19.02 years if the $\mathrm{PM}_{2.5}$ exposure were reduced to the cut-off level. Table 5 also shows that the survival probabilities have a linear relationship with hazard rates; an increase in one results in the decrease of the other with the sum of the two equal to one. Figures 2 and 3 show the AirQ+ life table evaluation for the year 2015 at the measured $\mathrm{PM}_{2.5}$ level $\left(87.9 \mu \mathrm{g} / \mathrm{m}^{3}\right)$ and year 2045 (30-year forecast) at the reduced cut-off level $\left(35 \mu \mathrm{g} / \mathrm{m}^{3}\right)$, respectively. For instance, the population at age 30 in 2015 was 18,576 with 18,571 years of life $(0.07 \%$ hazard rate and survival probability of $99.93 \%$ ); this number increases to 32,633 in 2045 with 32,624 years of life $(0.06 \%$ hazard rate and survival probability of $99.94 \%)$. The years of life and survival probabilities increase with increasing age; for instance, in 2045, it is forecasted that at age 65, the years of life increase from 14,102 (1.54\% hazard rate and survival probability of $98.46 \%)$ to $14,413(1.23 \%$ hazard rate and survival probability of $98.77 \%$ ), a $2 \%$ increase in years of life caused by reducing the annual mean concentration of $\mathrm{PM}_{2.5}$ from $87.9 \mu \mathrm{g} / \mathrm{m}^{3}$ to the cut-off value of $35 \mu \mathrm{g} / \mathrm{m}^{3}$. Figure 3 shows that the mid-year population after age 40 decreases exponentially, suggesting that the years of life decrease with increasing adult age reaching a minimum at ages $\geq 85$.

Table 4. Years of Life Lost (YLL) due to premature mortality.

\begin{tabular}{ccccc}
\hline Measure & Age & Central & Lower & Upper \\
\hline YLL-2015 & all ages & 252.18 & 170.69 & 322.92 \\
YLL-2015 & age 0-64 & 89.53 & 60.60 & 114.64 \\
YLL over 10 Years-2025 & all ages & $27,474.61$ & $18,483.02$ & $35,370.58$ \\
YLL over 10 Years-2025 & age 0-64 & 8487.28 & 5741.46 & $10,873.33$ \\
\hline
\end{tabular}

Values are written as $95 \%$ confidence interval: central (lower-upper). 
Table 5. Expected Life Remaining (ELR) and other parameters for different age groups.

\begin{tabular}{ccccccc}
\hline Age & $\begin{array}{c}\text { ELR } \\
\text { (years) }\end{array}$ & Delta ELR * & $\begin{array}{c}\text { Entry } \\
\text { Population }\end{array}$ & Years of Life & Hazard Rate & $\begin{array}{c}\text { Survival } \\
\text { Probability }\end{array}$ \\
\hline 0 & 79.81 & $2.65(1.35,4.51)$ & 33,269 & 33,242 & $0.16 \%$ & $99.84 \%$ \\
1 & 78.94 & $2.66(1.35,4.52)$ & 33,215 & 33,189 & $0.16 \%$ & $99.84 \%$ \\
30 & 51.12 & $2.34(1.53,3.08)$ & 18,576 & 18,571 & $0.06 \%$ & $99.94 \%$ \\
35 & 46.29 & $2.31(1.51,3.05)$ & 15,735 & 15,730 & $0.07 \%$ & $99.93 \%$ \\
40 & 41.47 & $2.28(1.49,3.01)$ & 13,885 & 13,878 & $0.11 \%$ & $99.89 \%$ \\
45 & 36.73 & $2.24(1.47,2.96)$ & 12,123 & 12,113 & $0.16 \%$ & $99.84 \%$ \\
50 & 32.08 & $2.19(1.43,2.89)$ & 9910 & 9898 & $0.25 \%$ & $99.75 \%$ \\
55 & 27.54 & $2.12(1.39,2.81)$ & 7564 & 7550 & $0.38 \%$ & $99.62 \%$ \\
60 & 23.14 & $2.04(1.33,2.70)$ & 5561 & 5542 & $0.66 \%$ & $99.34 \%$ \\
65 & 19.02 & $1.93(1.26,2.56)$ & 3895 & 3871 & $1.23 \%$ & $98.77 \%$ \\
70 & 15.36 & $1.78(1.16,2.36)$ & 2812 & 2782 & $2.16 \%$ & $97.84 \%$ \\
75 & 12.25 & $1.58(1.03,2.10)$ & 1939 & 1907 & $3.29 \%$ & $96.71 \%$ \\
80 & 9.54 & $1.37(0.89,1.81)$ & 1042 & 1014 & $5.28 \%$ & $94.72 \%$ \\
85 & 7.46 & $1.10(0.72,1.45)$ & 381 & 364 & $8.47 \%$ & $91.53 \%$ \\
\hline
\end{tabular}

* Obtained using the lower and upper estimates of the RR values.

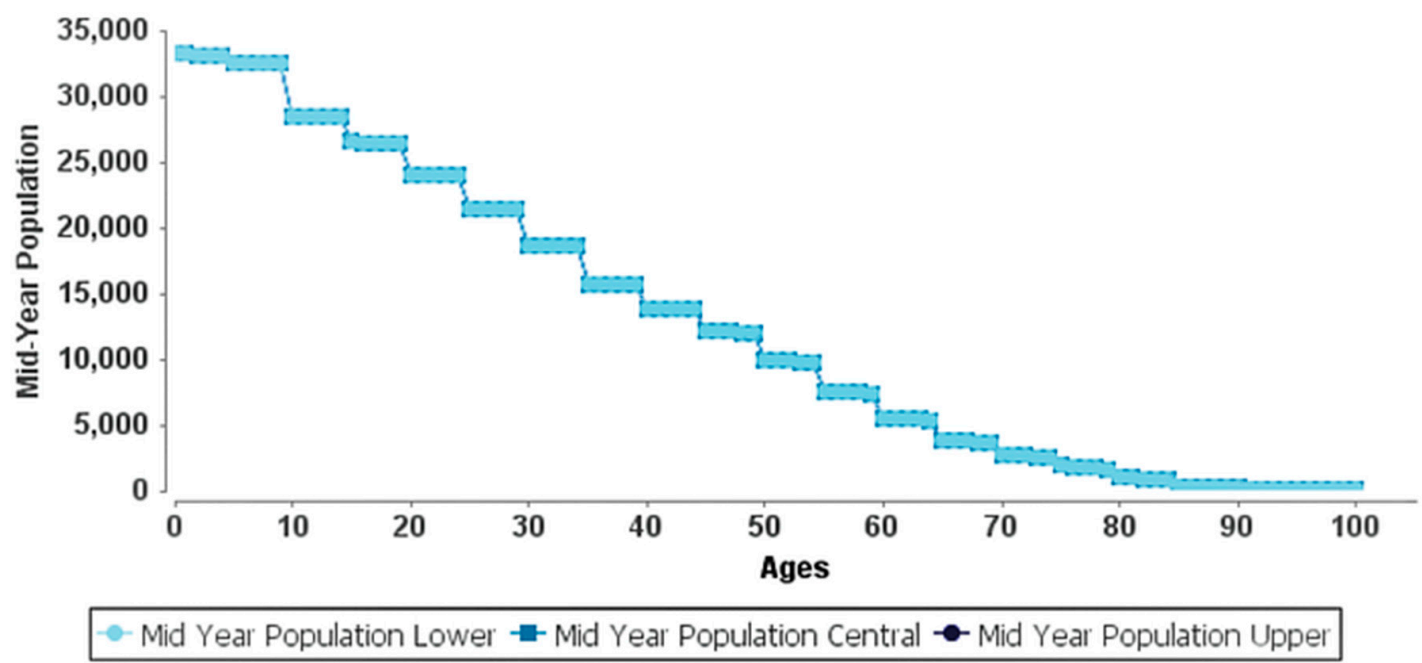

Figure 2. AirQ+ life table evaluation for the year 2015 at the measured $\mathrm{PM}_{2.5}$ level $\left(87.9 \mu \mathrm{g} / \mathrm{m}^{3}\right)$.

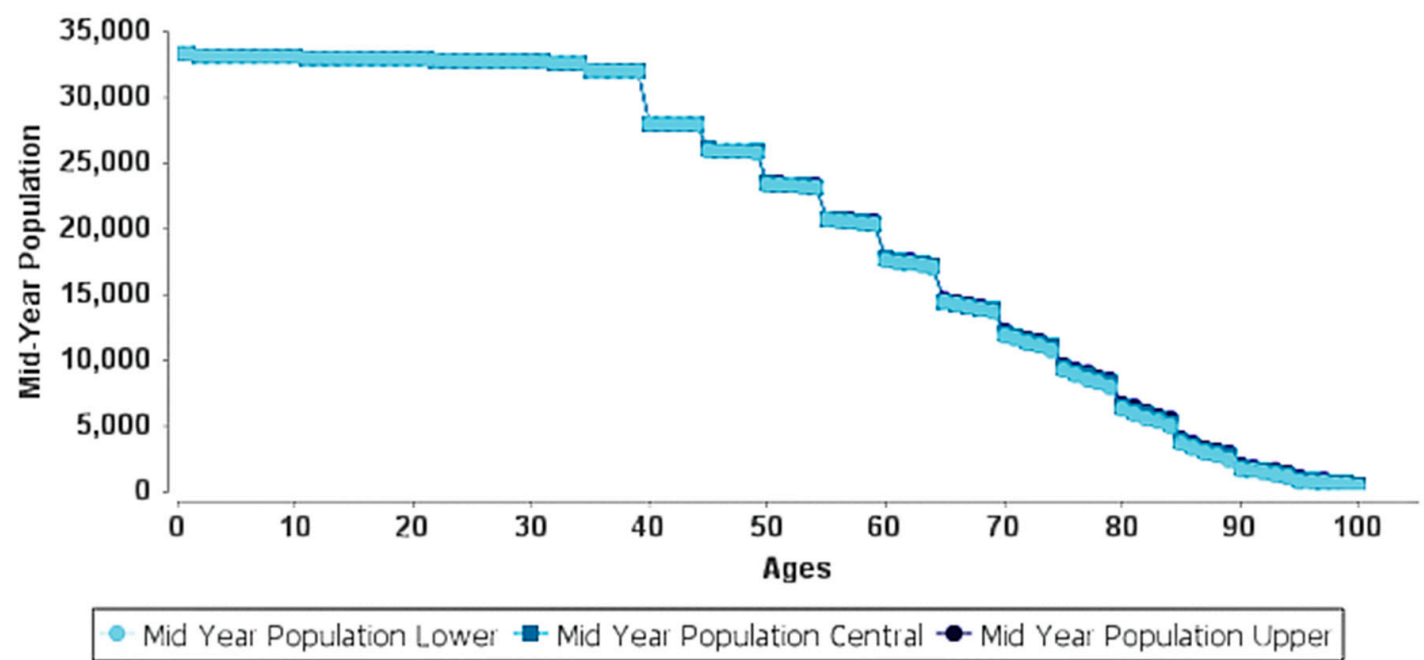

Figure 3. AirQ+ life table evaluation for the year 2045 (30-year forecast) if $\mathrm{PM}_{2.5}$ is reduced to the cut-off level $\left(35 \mu \mathrm{g} / \mathrm{m}^{3}\right)$. 


\subsection{Postneonatal Infant Mortality}

The total infant population was estimated at 32,062 during 2015 in Kuwait. A total of 76 postneonatal infant mortalities were recorded with the probability of occurrence, i.e., the baseline incidence of 237.04 per 100,000. The ELR and other parameters for postneonatal infant mortalities (for age groups 0 and 1 ) were shown previously in Table 5 . The estimated numbers of years that newborns and one-year old children are expected to live are 79.81 and 78.94 years, respectively. A total of 2.65 years (95\% CI: $1.35-4.51)$ and 2.66 years (95\% CI: $1.35-4.52)$ are gained for newborns and 1-year-old children, respectively, if the PM 10 value was lowered to the WHO IT-1 target $\left(70 \mu \mathrm{g} / \mathrm{m}^{3}\right)$ from the current exposure level of $167.5 \mu \mathrm{g} / \mathrm{m}^{3}$. It is worth noting that for a newborn, the ELR is identical to the life expectancy at birth. The entry population at age 1 was estimated as 33,215 with years of life approximation at 33,189 , corresponding to a survival probability of $99.84 \%$ at a hazard rate of $0.16 \%$.

Table 6 presents the attributable proportion (AP), excess cases, and excess incidence (per 100,000 at risk) for the postneonatal infant mortality associated with the $\mathrm{PM}_{10}$ exposure of $167.5 \mu \mathrm{g} / \mathrm{m}^{3}$. The AP of postneonatal mortality due to $\mathrm{PM}_{10}$ exposure was estimated at $22.68 \%$ (95\% CI: 12.18-35.84). A total of 17 excess death cases were attributed to the $\mathrm{PM}_{10}$ exposure, which is equivalent to an excess incidence of 53.77 per 100,000 (95\% CI: 28.87-84.95). The relative risk (RR) was calculated as 1.293; that is with every $70 \mu \mathrm{g} / \mathrm{m}^{3}$ increase in annual average $\mathrm{PM}_{10}$ concentration, the associated postneonatal infant mortality increased by $29.3 \%$.

Table 6. Postneonatal infant mortality with the associated parameters.

\begin{tabular}{|c|c|c|c|}
\hline & Central & Lower & Upper \\
\hline $\mathrm{AP}^{*}$ & $22.68 \%$ & $12.18 \%$ & $35.84 \%$ \\
\hline Excess Cases ** & 17 & 9 & 27 \\
\hline Cases per $100,000 * * *$ & 53.77 & 28.87 & 84.95 \\
\hline
\end{tabular}

* Attributable Proportion. ${ }^{* *}$ Excess number of cases attributed to $\mathrm{PM}_{10}$ exposure. ${ }^{* *}$ Excess incidence (cases per 100,000 at risk).

\subsection{Sensitivity Analysis}

Results of the sensitivity analysis for YLL and premature mortality for different age groups are shown in Table 7 and Figure 4. For all ages, reduction of the $\mathrm{PM}_{2.5}$ exposure from the current level $\left(87.9 \mu \mathrm{g} / \mathrm{m}^{3}\right)$ to the cut-off level $\left(35 \mu \mathrm{g} / \mathrm{m}^{3}\right)$ would increase the years of life from 2,088,845 years to $2,111,318$ years $(1.08 \%$ ) after a 30 -year forecast (year 2045). However, when considering only the adults $\geq 30$ years, the years of life would increase by $2.04 \%$ from 1,101,798 years to 1,124,271 years. The chi-squared test for adults $\geq 30$ years showed that the years of life are significantly different between the current and the cut-off levels, indicating that life expectancy for older adults would increase more by the reduction of $\mathrm{PM}_{2.5}$ exposure levels $\left(\chi^{2}=71.327, p \leq 0.01\right.$, Sig $\left.=0.000\right)$. Moreover, the years of life would increase by $6.67 \%$ from 294,436 years to 314,091 years for the elderly ( $\geq 60$ years). 
Table 7. Sensitivity analysis for YLL and premature mortality for different age groups.

\begin{tabular}{ccccccccc}
\hline \multirow{2}{*}{ Age } & \multicolumn{3}{c}{ Years of Life at the Current $\mathbf{P M}_{\mathbf{2 . 5}}$} & \multicolumn{3}{c}{ Years of Life at the Cut-Off $\mathbf{P M}_{\mathbf{2 . 5}}$} \\
\cline { 2 - 9 } & $\mathbf{2 0 1 5}$ & $\mathbf{2 0 2 5}$ & $\mathbf{2 0 3 5}$ & $\mathbf{2 0 4 5}$ & $\mathbf{2 0 1 5}$ & $\mathbf{2 0 2 5}$ & $\mathbf{2 0 3 5}$ & $\mathbf{2 0 4 5}$ \\
\hline $0-1$ & 66,431 & 66,431 & 66,431 & 66,431 & 66,431 & 66,431 & 66,431 & 66,431 \\
$2-9$ & 261,498 & 264,168 & 264,168 & 264,168 & 261,498 & 264,168 & 264,168 & 264,168 \\
$10-19$ & 274,269 & 326,535 & 329,197 & 329,197 & 274,269 & 326,535 & 329,197 & 329,197 \\
$20-29$ & 226,802 & 271,655 & 324,606 & 327,251 & 226,802 & 271,655 & 324,606 & 327,251 \\
$30-39$ & 171,239 & 225,351 & 270,909 & 322,526 & 171,251 & 225,508 & 271,099 & 322,757 \\
$40-49$ & 129,500 & 169,332 & 222,815 & 267,848 & 129,521 & 169,714 & 223,473 & 268,644 \\
$50-59$ & 86,543 & 126,119 & 164,919 & 216,988 & 86,576 & 126,807 & 166,172 & 218,779 \\
$60-69$ & 45,971 & 80,746 & 117,527 & 153,736 & 46,022 & 81,899 & 119,836 & 157,075 \\
$70-79$ & 21,891 & 37,249 & 65,321 & 94,749 & 21,962 & 38,888 & 69,098 & 100,819 \\
$\geq 80$ & 7251 & 14,884 & 26,376 & 45,951 & 7314 & 16,929 & 31,683 & 56,197 \\
\hline
\end{tabular}

Pearson Chi-Square $\left(\chi^{2}\right)($ for ages $\geq 30)=71.327, \mathrm{df}=3$, Sig $=0.000$. Pearson Chi-Square $\left(\chi^{2}\right)($ for ages $\geq 60)=132.10$, $\mathrm{df}=3$, Sig $=0.000$.

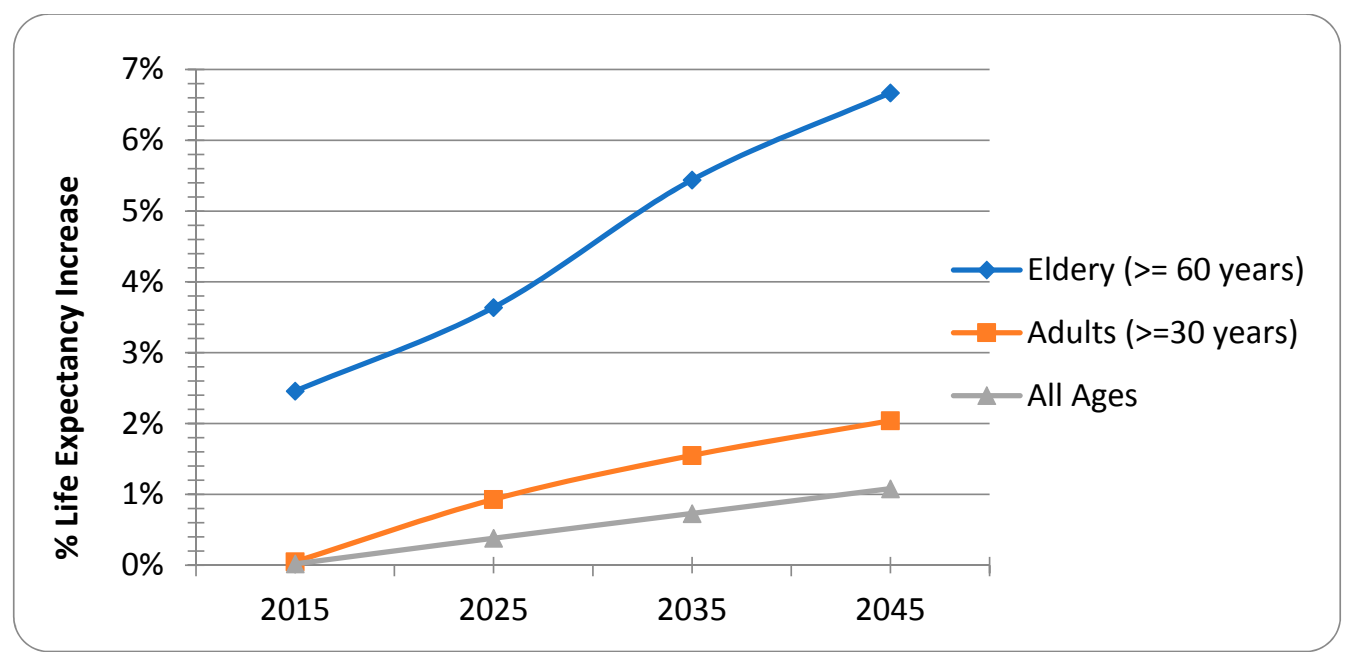

Figure 4. Sensitivity analysis for \% of life expectancy for the years 2015, 2025, 2035, 2045.

\section{Discussion}

DALYs's use in the quantification of the BOD is a systematic, scientific technique to estimate the comparative magnitude of health loss due to diseases and risk factors by age for specific points in time. DALYs's use in estimating the health loss can be measured through premature deaths (YLL) and/or non-fetal disability (YLD). This study estimated only the first component in the DALYs equation, which is the YLL. The standard life tables received from the NCHI of Kuwait Ministry of Health were confined to compute the YLL at each age. The nature of life tables obtained did not enable us to measure the YLD or perform any age-sex group comparison. The AirQ+ model used in this study did not discount the YLLs for time or age. The assumption was made to treat a year of healthy life as equal irrespective of the age at which it is lived [20]. This assumption was shown to be conceptually and scientifically correct $[27,29]$ because age-weights allow for bias in valuing life years in different age ranges $[65,66]$ and time-weights distinguish the relative value of healthy life lost in different time periods [67]. Time and age discount-drop in the calculations of YLL were also applied in similar studies $[43,47,49,68,69]$. DALYs methodology using the life-table approach has been adopted by the WHO Global Burden of Disease as a standardized method for ease of comparison of life losses across countries. Life-table parameters, including age, gender, mortality counts, incidence counts, population counts, disease duration, and disability weights are needed in order to calculate the DALYs. The strength of using the life-table approach is the provision of the overall measure 
of mortality and morbidity, allowing countries and regions to be compared and therefore provides a comparative assessment of the mortality rates and ill-health effects of a certain population's lifetime.

The YLL of premature mortalities for 2015 and for the next 10 years were estimated at 252.18 and $27,474.61$, respectively assuming that the annual average $\mathrm{PM}_{2.5}$ concentration $\left(87.9 \mu \mathrm{g} / \mathrm{m}^{3}\right)$ does not change over this period. The YLL estimated for Kuwait was lower than the YLL estimated for Northern Italy (433 YLL in 2007) [43], Tallinn, Estonia (3859 YLL in 2006) [47], and Tehran, Iran (67, 970 YLL in 2015) [49]. Scaling these numbers to the rate per 100,000 residents revealed that Kuwait was much lower YLL (19.5) relative to Northern Italy (2586), Tallinn (988), and Tehran (786), especially when taking into account its higher $\mathrm{PM}_{2.5}$ concentration $\left(87.9 \mu \mathrm{g} / \mathrm{m}^{3}\right)$ relative to Northern Italy $\left(42 \mu \mathrm{g} / \mathrm{m}^{3}\right)$, Tallinn $\left(11.6 \mu \mathrm{g} / \mathrm{m}^{3}\right)$ and Tehran $\left(26 \mu \mathrm{g} / \mathrm{m}^{3}\right)$. Although the reference years of Northern Italy and Tallinn are not directly comparable to Kuwait's reference year, the YLL calculated provides information on the consistency of the results obtained by the AirQ+ model. This study also showed that at the current concentration level, the average life expectancy of a 30-year-old person is reduced by more than 2 years, while the average decrease in life expectancy at birth was roughly 3 years, corresponding to an AP of $22.68 \%$ and 17 excess cases (53.77 per 100,000). Pope (2000) reported that the US population as a whole loses 1-3 years of life due to $\mathrm{PM}_{2.5}$ exposure. A study by Boldo, Medina [70] of 23 European cities reported that the average life expectancy at birth would increase more than 2 years if $\mathrm{PM}_{2.5}$ exposure was reduced in heavily polluted cities, such as Bucharest and Rome. In a WHO report, the average life expectancy at birth from all European Union populations was estimated to be shortened by 8.6 months due to $\mathrm{PM}_{2.5}$ exposure, and with proper air quality control measures, the average life expectancy would increase by 2.3 months by 2020, equating to an annual avoidance of one million YLL [47].

Sensitivity analysis showed that reduction of the current $\mathrm{PM}_{2.5}$ level to the WHO IT- 1 interim target of $35 \mu \mathrm{g} / \mathrm{m}^{3}$ would increase life expectancy and reduce the hazard rate of premature adult mortality from $0.07-10.58 \%$ to $0.06-8.47 \%$ for age groups between 30 and 85 for the year 2045 . Negative health endpoints were shown to be associated with high-risk groups, such as people with pre-diagnosed respiratory or cardiovascular diseases or the elderly [71]. Kuwait's older populations with high background rates of cardiovascular diseases, i.e., ischemic heart disease and stroke, may have contributed to the higher YLL rate at older ages [72]. Regions with older-than-average populations and high underlying rates of cardiovascular disease (e.g., the former Soviet Union) tend to have higher rates of attributable mortalities at higher ages [13].

Without underrating the postneonatal infant mortalities from exposure to coarse particles $\left(\mathrm{PM}_{10}\right)$, only part of the total BOD is captured since the YLLs are generally unknown. Short-term effects of PM are only one-tenth to one-fifth of the overall effect from long-term exposure [73]; therefore, the long-term exposure estimates of $\mathrm{PM}_{2.5}$ are better indicators of premature mortalities and DALYs. Avoiding death from a $\mathrm{PM}_{2.5}$ exposure does not necessarily mean saving a life; however, $\mathrm{PM}_{2.5}$ exposure substantially reduces life expectancy [74].

The AirQ+ model was selected to quantify the BOD associated with premature adult mortalities due to $\mathrm{PM}_{2.5}$ exposure and postneonatal infant mortalities due to $\mathrm{PM}_{10}$ exposure in terms of the YLL using life tables, but it has limitations. The model does not allow for the calculation of the YLD which is considered important to properly evaluate the DALYs for a comprehensive health impact assessment in terms of time lived with disability. The model's long-term effects of PM are calculated based on risk estimates from cohort studies carried out in the USA and Europe [11,59,75], where concentrations are low and consequently, may overestimate the BOD in hot arid environments with higher PM concentrations, such as Kuwait, given the high intensity and frequency of dust storms [76-79]. However, based on the recommendations of the WHO technical officer (personal communication) the use of the linear-log calculation method would offset such overestimation. The AirQ+/AirQ2.2 model was shown to be a valid and reliable tool to estimate the potential health impacts from short-term exposures [44,63]. More research is needed on the AirQ+ model to enhance the calculation of health outcome from long-term exposures [80]. 
Future studies are needed to estimate the age-sex-geography health impacts of DALYs in Kuwait. No health assessment studies using the AirQ+ models of life tables were previously conducted to estimate the combination of age-sex-geography risk. Studies with longer time scale durations are required. Other DALYs from water-borne or food-borne exposures should be also investigated [81,82], however, the YLLs and YLDs from these diseases may not be critical for Kuwait given the high standards of living and the provision of adequate sanitary and food safety measures.

Author Contributions: A.A.-H. developed the research methodology, analyzed the data using the AirQ+ model and wrote the original draft; J.G. confirmed the research method, validated the $\mathrm{PM}_{10} / \mathrm{PM}_{2.5}-\mathrm{morbidity}$ association and reviewed the manuscript; A.N.A.-D. analyzed the $\mathrm{PM}_{2.5}$ data and reviewed the manuscript; A.A.-S. defined the health characteristics of morbidity and mortality; A.A.-K. carried out the statistical analysis using SPSS.

Funding: This research was funded by the Kuwait Foundation for the Advancement of Sciences (KFAS), grant number [PR17-12SL-05], project number [EC101C].

Acknowledgments: This study is part of the Kuwait Institute for Scientific Research (KISR) project no. EC109K funded by the Kuwait Environment Public Authority (KEPA) (Grant 24-08-16) and EC101C (Grant PR-17-12SL-05) funded by KFAS. The authors are grateful to Abdullah M. Alajeel from Kuwait National Center for Health Information in the Ministry of Health for providing the mortality/morbidity data and life tables. Special thanks also go to KEPA for providing the air quality data. The authors would like to thank Ms. Weam Behbehani from KISR's Techno-Economics Department and Eng. Ahmed Abdulhadi from KISR's GIS section for their technical assistance in data analysis and data representation.

Conflicts of Interest: The authors declare no conflict of interest.

\section{References}

1. Atkinson, R.; Kang, S.; Anderson, H.; Mills, I.; Walton, H. Epidemiological time series studies of $\mathrm{PM}_{2.5}$ and daily mortality and hospital admissions: A systematic review and meta-analysis. Thorax 2014, 69, 660-665. [CrossRef] [PubMed]

2. Crouse, D.L.; Peters, P.A.; Hystad, P.; Brook, J.R.; van Donkelaar, A.; Martin, R.V.; Villeneuve, P.J.; Jerrett, M.; Goldberg, M.S.; Pope, C.A., III; et al. Ambient $\mathrm{PM}_{2.5}, \mathrm{O}_{3}$, and $\mathrm{NO}_{2}$ exposures and associations with mortality over 16 years of follow-up in the Canadian Census Health and Environment Cohort (CanCHEC). Environ. Health Perspect. 2015, 123, 1180. [CrossRef] [PubMed]

3. Liu, J.; Han, Y.; Tang, X.; Zhu, J.; Zhu, T. Estimating adult mortality attributable to $\mathrm{PM}_{2.5}$ exposure in China with assimilated $\mathrm{PM}_{2.5}$ concentrations based on a ground monitoring network. Sci. Total Environ. 2016, 568, 1253-1262. [CrossRef] [PubMed]

4. World Health Organization (WHO). Ambient Air Pollution: A Global Assessment of Exposure and Burden of Disease; WHO: Geneva, Switzerland, 2016.

5. World Health Organization (WHO). Air Quality Guidelines: Global Update 2005; WHO: Geneva, Switzerland, 2016.

6. Son, J.-Y.; Lee, H.J.; Koutrakis, P.; Bell, M.L. Pregnancy and Lifetime Exposure to Fine Particulate Matter and Infant Mortality in Massachusetts, 2001-2007. Am. J. Epidemiol. 2017, 186, 1268-1276. [CrossRef] [PubMed]

7. Yorifuji, T.; Kashima, S.; Doi, H. Acute exposure to fine and coarse particulate matter and infant mortality in Tokyo, Japan (2002-2013). Sci. Total Environ. 2016, 551, 66-72. [CrossRef] [PubMed]

8. Cambra, K.; Alonso, E.; Medina, S.; Letertre, A.; Cassadou, S.; Pascal, L.; Frank, F.; Dequijano, E.D.; Valero, N.; Knudsen, L.; et al. Health Impact Assessment of $\mathrm{PM}_{10}$ Air Pollution on Postneonatal Mortality in 31 European Cities. Epidemiology 2006, 17, S106. [CrossRef]

9. Paldy, A.; Bobvos, J.; Lustigova, M.; Moshammer, H.; Niciu, E.M.; Otorepec, P.; Puklova, V.; Szafraniec, K.; Zagargale, T.; Neuberger, M.; et al. Health impact assessment of $\mathrm{PM}_{10}$ on mortality and morbidity in children in central-eastern european cities. Epidemiology 2006, 17, S131. [CrossRef]

10. Kaiser, R.; Romieu, I.; Medina, S.; Schwartz, J.; Krzyzanowski, M.; Künzli, N. Air pollution attributable postneonatal infant mortality in US metropolitan areas: A risk assessment study. Environ. Health 2004, 3, 4. [CrossRef] [PubMed]

11. Pope, C.A.; Burnett, R.T.; Thun, M.J.; Calle, E.E.; Krewski, D.; Ito, K.; Thurston, G.D. Lung cancer, cardiopulmonary mortality, and long-term exposure to fine particulate air pollution. JAMA 2002, 287, 1132-1141. [CrossRef] [PubMed] 
12. Dockery, D.W.; Pope, C.A.; Xu, X.; Spengler, J.D.; Ware, J.H.; Fay, M.E.; Ferris, B.G., Jr.; Speizer, F.E. An association between air pollution and mortality in six US cities. N. Engl. J. Med. 1993, 329, 1753-1759. [CrossRef] [PubMed]

13. Apte, J.S.; Marshall, J.D.; Cohen, A.J.; Brauer, M. Addressing global mortality from ambient $\mathrm{PM}_{2.5}$. Environ. Sci. Technol. 2015, 49, 8057-8066. [CrossRef] [PubMed]

14. Beelen, R.; Raaschou-Nielsen, O.; Stafoggia, M.; Andersen, Z.J.; Weinmayr, G.; Hoffmann, B.; Wolf, K.; Samoli, E.; Fischer, P.; Nieuwenhuijsen, M.; et al. Effects of long-term exposure to air pollution on natural-cause mortality: An analysis of 22 European cohorts within the multicentre ESCAPE project. Lancet 2014, 383, 785-795. [CrossRef]

15. Krewski, D.; Jerrett, M.; Burnett, R.T.; Ma, R.; Hughes, E.; Shi, Y.; Turner, M.C.; Pope, C.A., III; Thurston, G.; Calle, E.E.; et al. Extended Follow-Up and Spatial Analysis of the American Cancer Society Study Linking Particulate Air Pollution and Mortality; Health Effects Institute: Boston, MA, USA, 2009.

16. Lepeule, J.; Laden, F.; Dockery, D.; Schwartz, J. Chronic exposure to fine particles and mortality: An extended follow-up of the Harvard Six Cities study from 1974 to 2009. Environ. Health Perspect. 2012, 120, 965-970. [CrossRef] [PubMed]

17. Ostro, B.; Hu, J.; Goldberg, D.; Reynolds, P.; Hertz, A.; Bernstein, L.; Kleeman, M.J. Associations of mortality with long-term exposures to fine and ultrafine particles, species and sources: Results from the California Teachers Study Cohort. Environ. Health Perspect. 2015, 123, 549. [CrossRef] [PubMed]

18. Ostro, B.; Lipsett, M.; Reynolds, P.; Goldberg, D.; Hertz, A.; Garcia, C.; Henderson, K.D.; Bernstein, L. Long-term exposure to constituents of fine particulate air pollution and mortality: Results from the California Teachers Study. Environ. Health Perspect. 2010, 118, 363. [CrossRef] [PubMed]

19. Lim, S.S.; Vos, T.; Flaxman, A.D.; Danaei, G.; Shibuya, K.; Adair-Rohani, H.; AlMazroa, M.A.; Amann, M.; Anderson, H.R.; Andrews, K.G.; et al. A comparative risk assessment of burden of disease and injury attributable to 67 risk factors and risk factor clusters in 21 regions, 1990-2010: A systematic analysis for the Global Burden of Disease Study 2010. Lancet 2012, 380, 2224-2260. [CrossRef]

20. Murray, C.J.; Ezzati, M.; Flaxman, A.D.; Lim, S.; Lozano, R.; Michaud, C.; Naghavi, M.; Salomon, J.A.; Shibuya, K.; Vos, T.; et al. GBD 2010: Design, definitions, and metrics. Lancet 2012, 380, 2063-2066. [CrossRef]

21. Cohen, A.J.; Brauer, M.; Burnett, R.; Anderson, H.R.; Frostad, J.; Estep, K.; Balakrishnan, K.; Brunekreef, B.; Dandona, L.; Dandona, R.; et al. Estimates and 25-year trends of the global burden of disease attributable to ambient air pollution: An analysis of data from the Global Burden of Diseases Study 2015. Lancet 2017, 389, 1907-1918. [CrossRef]

22. Woodruff, T.J.; Darrow, L.A.; Parker, J.D. Air pollution and postneonatal infant mortality in the United States, 1999-2002. Environ. Health Perspect. 2007, 116, 110-115. [CrossRef] [PubMed]

23. Woodruff, T.J.; Grillo, J.; Schoendorf, K.C. The relationship between selected causes of postneonatal infant mortality and particulate air pollution in the United States. Environ. Health Perspect. 1997, 105, 608. [CrossRef] [PubMed]

24. Ha, E.-H.; Lee, J.-T.; Kim, H.; Hong, Y.-C.; Lee, B.-E.; Park, H.-S.; Christiani, D.C. Infant susceptibility of mortality to air pollution in Seoul, South Korea. Pediatrics 2003, 111, 284-290. [CrossRef] [PubMed]

25. Pharoah, P.; Morris, J. Postneonatal mortality. Epidemiol. Rev. 1979, 1, 170-183. [CrossRef] [PubMed]

26. Geelen, L.M.; Huijbregts, M.A.; den Hollander, H.; Ragas, A.M.; van Jaarsveld, H.A.; de Zwart, D. Confronting environmental pressure, environmental quality and human health impact indicators of priority air emissions. Atmos. Environ. 2009, 43, 1613-1621. [CrossRef]

27. Gao, T.; Wang, X.C.; Chen, R.; Ngo, H.H.; Guo, W. Disability adjusted life year (DALY): A useful tool for quantitative assessment of environmental pollution. Sci. Total Environ. 2015, 511, 268-287. [CrossRef] [PubMed]

28. Valent, F.; Bertollini, R.; Nemer, L.E.; Barbone, F.; Tamburlini, G. Burden of disease attributable to selected environmental factors and injury among children and adolescents in Europe. Lancet 2004, 363, 2032-2039. [CrossRef]

29. Murray, C.J.; Acharya, A. Age weights and discounting in health gaps reconsidered. In Summary Measures of Population Health; Book Chapter; CiteSeer: University Park, PA, USA, 2002.

30. Murray, C.J.; Lopez, A.D. Measuring global health: Motivation and evolution of the Global Burden of Disease Study. Lancet 2017, 390, 1460-1464. [CrossRef] 
31. Dwyer-Lindgren, L.; Stubbs, R.W.; Bertozzi-Villa, A.; Morozoff, C.; Callender, C.; Finegold, S.B.; Shirude, S.; Flaxman, A.D.; Laurent, A.; Kern, E.; et al. Variation in life expectancy and mortality by cause among neighbourhoods in King County, WA, USA, 1990-2014: A census tract-level analysis for the Global Burden of Disease Study 2015. Lancet Public Health 2017, 2, e400-e410. [CrossRef]

32. Chen, A.; Jacobsen, K.H.; Deshmukh, A.A.; Cantor, S.B. The evolution of the disability-adjusted life year (DALY). Socio-Econ. Plan. Sci. 2015, 49, 10-15. [CrossRef]

33. Prüss-Üstün, A.; Mathers, C.; Corvalán, C.; Woodward, A. Introduction and Methods: Assessing the Environmental Burden of Disease at National and Local Levels; World Health Organization: Geneva, Switzerland, 2003.

34. Ragas, A.M.; Oldenkamp, R.; Preeker, N.; Wernicke, J.; Schlink, U. Cumulative risk assessment of chemical exposures in urban environments. Environ. Int. 2011, 37, 872-881. [CrossRef] [PubMed]

35. Haagsma, J.A.; Polinder, S.; Stein, C.E.; Havelaar, A.H. Systematic review of foodborne burden of disease studies: Quality assessment of data and methodology. Int. J. Food Microbiol. 2013, 166, 34-47. [CrossRef] [PubMed]

36. Prüss-Ustün, A.; Vickers, C.; Haefliger, P.; Bertollini, R. Knowns and unknowns on burden of disease due to chemicals: A systematic review. Environ. Health 2011, 10, 9. [CrossRef] [PubMed]

37. WHO. Assessing the Environmental Burden of Disease at National and Local Levels; Fewtrell, L., Kaufmann, R., Prüss-Üstün, A., Eds.; World Health Organization: Geneva, Switzerland, 2003.

38. Prüss, A.; Kay, D.; Fewtrell, L.; Bartram, J. Estimating the burden of disease from water, sanitation, and hygiene at a global level. Environ. Health Perspect. 2002, 110, 537. [CrossRef] [PubMed]

39. Chen, C.-J.; Shih, T.-S.; Chang, H.-Y.; Yu, H.-S.; Wu, J.-D.; Sheu, S.-C.; Wu, C.-E.; Chou, T.-C. The total body burden of chromium associated with skin disease and smoking among cement workers. Sci. Total Environ. 2008, 391, 76-81. [CrossRef] [PubMed]

40. Mathers, C.D.; Loncar, D. Projections of global mortality and burden of disease from 2002 to 2030. PLoS Med. 2006, 3, e442. [CrossRef] [PubMed]

41. Salomon, J.A. Disability-Adjusted Life Years. In Encyclopedia of Health Economics; Culyer, A.J., Ed.; Elsevier: San Diego, CA, USA, 2014; pp. 200-203.

42. Murray, C.J.; Lopez, A.D.; World Health Organization. The Global Burden of Disease: A Comprehensive Assessment of Mortality and Disability from Diseases, Injuries, and Risk Factors in 1990 and Projected to 2020: Summary; Published by the Harvard School of Public Health on behalf of The World Health Organization and The World Bank; Harvard University Press: Cambridge, MA, USA, 1996; ISBN 0-9655466-0-8.

43. Fattore, E.; Paiano, V.; Borgini, A.; Tittarelli, A.; Bertoldi, M.; Crosignani, P.; Fanelli, R. Human health risk in relation to air quality in two municipalities in an industrialized area of Northern Italy. Environ. Res. 2011, 111, 1321-1327. [CrossRef] [PubMed]

44. Tominz, R.; Mazzoleni, B.; Daris, F. Estimate of potential health benefits of the reduction of air pollution with $\mathrm{PM}_{10}$ in Trieste, Italy. Epidemiol. Prev. 2005, 29, 149-155. [PubMed]

45. Skotak, K.; Swiatczak, J. Potential human health effects of $\mathrm{PM}_{10}$ exposure in Poland. Prz. Lek. 2008, 65, 18-25. [PubMed]

46. Moustris, K.P.; Ntourou, K.; Nastos, P.T. Estimation of particulate matter impact on human health within the urban environment of Athens City, Greece. Urban Sci. 2017, 1, 6. [CrossRef]

47. Orru, H.; Teinemaa, E.; Lai, T.; Tamm, T.; Kaasik, M.; Kimmel, V.; Kangur, K.; Merisalu, E.; Forsberg, B. Health impact assessment of particulate pollution in Tallinn using fine spatial resolution and modeling techniques. Environ. Health 2009, 8, 7. [CrossRef] [PubMed]

48. Wheida, A.; Nasser, A.; El Nazer, M.; Borbon, A.; El Ata, G.A.A.; Wahab, M.A.; Alfaro, S.C. Tackling the mortality from long-term exposure to outdoor air pollution in megacities: Lessons from the Greater Cairo case study. Environ. Res. 2018, 160, 223-231. [CrossRef] [PubMed]

49. Faridi, S.; Shamsipour, M.; Krzyzanowski, M.; Künzli, N.; Amini, H.; Azimi, F.; Malkawi, M.; Momeniha, F.; Gholampour, A.; Hassanvand, M.S.; et al. Long-term trends and health impact of $\mathrm{PM}_{2.5}$ and $\mathrm{O}_{3}$ in Tehran, Iran, 2006-2015. Environ. Int. 2018, 114, 37-49. [CrossRef] [PubMed]

50. Ghozikali, M.G.; Heibati, B.; Naddafi, K.; Kloog, I.; Conti, G.O.; Polosa, R.; Ferrante, M. Evaluation of chronic obstructive pulmonary disease (COPD) attributed to atmospheric $\mathrm{O}_{3}, \mathrm{NO}_{2}$, and $\mathrm{SO}_{2}$ using Air Q Model (2011-2012 year). Environ. Res. 2016, 144, 99-105. [CrossRef] [PubMed] 
51. Goudarzi, G.; Daryanoosh, S.; Godini, H.; Hopke, P.; Sicard, P.; De Marco, A.; Rad, H.; Harbizadeh, A.; Jahedi, F.; Mohammadi, M.; et al. Health risk assessment of exposure to the Middle-Eastern Dust storms in the Iranian megacity of Kermanshah. Public Health 2017, 148, 109-116. [CrossRef] [PubMed]

52. Hadei, M.; Hashemi-Nazari, S.S.; Eslami, A.; Khosravi, A.; Yarahmadi, M.; Naghdali, Z.; Shahsavani, A. Distribution and number of ischemic heart disease (IHD) and stroke deaths due to chronic exposure to $\mathrm{PM}_{2.5}$ in 10 cities of iran (2013-2015); an airq+ modelling. J. Air Pollut. Health 2018, 2, 129-136.

53. Hopke, P.K.; Nazari, S.S.H.; Hadei, M.; Yarahmadi, M.; Kermani, M.; Yarahmadi, E.; Shahsavani, A. Spatial and Temporal Trends of Short-Term Health Impacts of $\mathrm{PM}_{2.5}$ in Iranian Cities; a Modelling Approach (2013-2016). Aerosol Air Qual. Res. 2018, 18, 497-504. [CrossRef]

54. Khaniabadi, Y.O.; Daryanoosh, M.; Sicard, P.; Takdastan, A.; Hopke, P.K.; Esmaeili, S.; de Marco, A.; Rashidi, R. Chronic obstructive pulmonary diseases related to outdoor $\mathrm{PM}_{10}, \mathrm{O}_{3}, \mathrm{SO}_{2}$, and $\mathrm{NO}_{2}$ in a heavily polluted megacity of Iran. Environ. Sci. Pollut. Res. 2018, 25, 17726-17734. [CrossRef] [PubMed]

55. Miri, M.; Aval, H.E.; Ehrampoush, M.H.; Mohammadi, A.; Toolabi, A.; Nikonahad, A.; Derakhshan, Z.; Abdollahnejad, A. Human health impact assessment of exposure to particulate matter: An AirQ software modeling. Environ. Sci. Pollut. Res. 2017, 24, 16513-16519. [CrossRef] [PubMed]

56. Habeebullah, T. Health impacts of $\mathrm{PM}_{10}$ using AirQ2. 2.3 model in Makkah. J. Basic Appl. Sci. 2013, 9, $259-268$.

57. Jeong, S.J. The impact of air pollution on human health in Suwon City. Asian J. Atmos. Environ. 2013, 7, 227-233. [CrossRef]

58. Pascal, M.; Corso, M.; Ung, A.; Declercq, C.; Medina, S. Improving Knowledge and Communication for Decision Making on Air Pollution and Health in Europe-Aphekom Project in Guidelines for Assessing the Health Impacts of Strategies to Reduce Air Pollution in Europe; French Institute for Public Health Surveillance: Saint-Maurice, France, 2011.

59. Ostro, B.; World Health Organization (WHO). Outdoor Air Pollution: Assessing the Environmental Burden of Disease at National and Local Levels; WHO: Geneva, Switzerland, 2004.

60. U.S. Environmental Protection Agency (USEPA). Review of the National Ambient Air Quality Standards for Particulate Matter: Policy Assessment of Scientific and Technical Information (OAQPS Staff Paper); USEPA: Research Triangle Park, NC, USA, 1996.

61. Ostro, B.D.; Hurley, S.; Lipsett, M.J. Air pollution and daily mortality in the Coachella Valley, California: A study of $\mathrm{PM}_{10}$ dominated by coarse particles. Environ. Res. 1999, 81, 231-238. [CrossRef] [PubMed]

62. Homedes, N. The Disability-Adjusted Life Year (DALY) Definition, Measurement and Potential Use; World Bank: Washington, DC, USA, 1996.

63. Conti, G.O.; Heibati, B.; Kloog, I.; Fiore, M.; Ferrante, M. A review of AirQ Models and their applications for forecasting the air pollution health outcomes. Environ. Sci. Pollut. Res. 2017, 24, 6426-6445. [CrossRef] [PubMed]

64. Héroux, M.-E.; Anderson, H.R.; Atkinson, R.; Brunekreef, B.; Cohen, A.; Forastiere, F.; Hurley, F.; Katsouyanni, K.; Krewski, D.; Krzyzanowski, M.; et al. Quantifying the health impacts of ambient air pollutants: Recommendations of a WHO/Europe project. Int. J. Public Health 2015, 60, 619-627. [CrossRef] [PubMed]

65. WHO. Review of Evidence on Health Aspects of Air Pollution: REVIHAAP Project: Final Technical Report; WHO Regional Office for Europe: København, Denmark, 2013.

66. Sudhir, A.; Kara, H. Disability-adjusted life years: A critical review. J. Health Econ. 1997, 16, 685-702.

67. Tsuchiya, A. Age weighting and time discounting: Technical imperative versus social choice. In Summary Measures of Population Health: Concepts, Ethics, Measurement and Applications; World Health Organization: Geneva, Switzerland, 2002.

68. van Zelm, R.; Huijbregts, M.A.; den Hollander, H.A.; Van Jaarsveld, H.A.; Sauter, F.J.; Struijs, J.; van Wijnen, H.J.; van de Meent, D.; et al. European characterization factors for human health damage of $\mathrm{PM}_{10}$ and ozone in life cycle impact assessment. Atmos. Environ. 2008, 42, 441-453. [CrossRef]

69. Kobayashi, Y.; Peters, G.M.; Ashbolt, N.J.; Shiels, S.; Khan, S.J. Assessing burden of disease as disability adjusted life years in life cycle assessment. Sci. Total Environ. 2015, 530-531, 120-128. [CrossRef] [PubMed]

70. Boldo, E.; Medina, S.; Le Tertre, A.; Hurley, F.; Mücke, H.-G.; Ballester, F.; Aguilera, I. Apheis: Health impact assessment of long-term exposure to $\mathrm{PM}_{2.5}$ in 23 European cities. Eur. J. Epidemiol. 2006, 21, 449-458. [CrossRef] [PubMed]

71. Nel, A. Air pollution-related illness: Effects of particles. Science 2005, 308, 804-806. [CrossRef] [PubMed] 
72. Al-Hemoud, A.; Al-Dabbous, A.N.; Gasana, J.; Al-Shatti, A. Burden of Disease Associated with Long- and Short-Term Exposures to High Ambient Concentrations of $\mathrm{PM}_{2.5}$ using AirQ+. Environ. Res. 2018. under review.

73. Künzli, N.; Medina, S.; Kaiser, R.; Quenel, P.; Horak, F., Jr.; Studnicka, M. Assessment of deaths attributable to air pollution: Should we use risk estimates based on time series or on cohort studies? Am. J. Epidemiol. 2001, 153, 1050-1055. [CrossRef] [PubMed]

74. Correia, A.W.; Pope, C.A., III; Dockery, D.W.; Wang, Y.; Ezzati, M.; Dominici, F. The effect of air pollution control on life expectancy in the United States: An analysis of 545 US counties for the period 2000 to 2007. Epidemiology 2013, 24, 23. [CrossRef] [PubMed]

75. Burnett, R.T.; Pope, C.A., III; Ezzati, M.; Olives, C.; Lim, S.S.; Mehta, S.; Shin, H.H.; Singh, G.; Hubbell, B.; Brauer, M.; et al. An integrated risk function for estimating the global burden of disease attributable to ambient fine particulate matter exposure. Environ. Health Perspect. 2014, 122, 397. [CrossRef] [PubMed]

76. Yassin, M.F.; Almutairi, S.K.; Al-Hemoud, A. Dust storms backward Trajectories' and source identification over Kuwait. Atmos. Res. 2018, 212, 158-171. [CrossRef]

77. Al-Hemoud, A.; Al-Sudairawi, M.; Neelamanai, S.; Naseeb, A.; Behbehani, W. Socioeconomic effect of dust storms in Kuwait. Arab. J. Geosci. 2017, 10, 18. [CrossRef]

78. Al-Dabbous, A.N.; Kumar, P. Number and size distribution of airborne nanoparticles during summertime in Kuwait: First observations from the Middle East. Environ. Sci. Technol. 2014, 48, 13634-13643. [CrossRef] [PubMed]

79. Al-Hemoud, A.; Al-Dousari, A.; Al-Shatti, A.; Al-Khayat, A.; Behbehani, W.; Malak, M. Health Impact Assessment Associated with Exposure to $\mathrm{PM}_{10}$ and Dust Storms in Kuwait. Atmosphere 2018, 9, 6. [CrossRef]

80. Popoola, L.; Adebanjo, S.; Adeoye, B. Assessment of atmospheric particulate matter and heavy metals: A critical review. Int. J. Environ. Sci. Technol. 2018, 1-14. [CrossRef]

81. Ashbolt, N.J. Microbial contamination of drinking water and human health from community water systems. Curr. Environ. Health Rep. 2015, 2, 95-106. [CrossRef] [PubMed]

82. Collier, S.; Stockman, L.; Hicks, L.; Garrison, L.; Zhou, F.; Beach, M. Direct healthcare costs of selected diseases primarily or partially transmitted by water. Epidemiol. Infect. 2012, 140, 2003-2013. [CrossRef] [PubMed] 